\title{
Inheritance of Complete Resistance to Pearl Millet Downy Mildew
}

\author{
S. D. Singh and B. S. Talukdar, International Crops Research Institute for the Semi-Arid Tropics, Patancheru, AP \\ 502324 , India
}

\begin{abstract}
Singh, S. D., and Talukdar, B. S. 1998. Inheritance of complete resistance to pearl millet downy mildew. Plant Dis. 82:791-793.

Inheritance of downy mildew (Sclerospora graminicola) resistance in pearl millet (Pennisetum glaucum) was studied in a cross involving DMRP (downy mildew resistant Pennisetum) 292 and DMSP (downy mildew susceptible Pennisetum) 23. DMRP 292, derived from IP 18292, and DMSP 23, derived from Tift 23DB, were made homozygous for downy mildew resistancesusceptibility by three generations of single plant selection following inoculations with homogenized sporangial population of $S$. graminicola from the ICRISAT Asia Center. Potted seedlings of parental lines, $\mathrm{F}_{1}, \mathrm{~F}_{2}$, and $\mathrm{BC}$ progenies were evaluated for their reactions to downy mildew following inoculation. The results show that complete resistance to downy mildew in DMRP 292 is controlled by a single dominant gene. Because of the simple mode of inheritance, resistance utilization from DMRP 292 is simple and straightforward. We designate this gene as $\mathrm{Rsg}_{1}$.
\end{abstract}

Additional keywords: incomplete resistance, recovery resistance

Downy mildew (Sclerospora graminicola (Sacc.) J. Schröt.) is the most widespread and destructive disease of pearl millet (Pennisetum glaucum (L.) R. Br.) in India and in African countries. Due to its systemic nature and its ability to flourish under a wide range of environmental conditions (16), the disease can cause considerable losses in grain yield $(3,10,13-15)$ and is particularly destructive in singlecross $F_{1}$ hybrids of pearl millet in India $(15,21)$. Due to the low economic value of pearl millet, the use of resistant cultivars is the most appropriate control method.

To produce disease resistant cultivars, information on the number of resistance genes and their pattern of inheritance is important. This information is somewhat unclear in previous studies, particularly in relation to dominance $(15,21)$, mainly because of the use of unreliable resistancescreening techniques, variable pathogen populations, and variable host parents. With the availability of highly reliable greenhouse screening techniques, which correlate with field screening $(17,21)$, the experiments were conducted in the green-

Corresponding author: S. D. Singh E-mail: S.D.SINGH@CGNET.COM

Current address of S. D. Singh: Cereals Pathology, ICRISAT Asia Center, Patancheru PO, Andhra Pradesh 502 324, India.

Submitted as J. A. No. 2088 of ICRISAT.

Accepted for publication 9 April 1998.

Publication no. D-1998-0520-01R

(C) 1998 The American Phytopathological Society house under controlled conditions. A study of inheritance of resistance, using a source of complete downy mildew resistance (15), was initiated in 1994. The results are reported in this paper.

\section{MATERIALS AND METHODS}

Source material and derivation of homozygous resistant and susceptible lines. A recently identified source of complete resistance, IP 18292 (15), was used to derive the resistant parent. IP 18292 is a genetic stock with a white leaf sheath, which is a morphologically distinct recessively inherited trait (1). Tift 23DB, with the $\mathrm{d}_{2}$ dwarf trait, developed at Tifton, Georgia, (4) was used as the susceptible parent. Tift 23DB was the seed parent of the most widely grown $\mathrm{F}_{1}$ hybrid, $\mathrm{HB} 3$, during the early 1970s in India. Later, production of the hybrid was discontinued due to its susceptibility to downy mildew.

Seeds of IP 18292 and Tift 23DB were sown in 25-cm-diameter pots (about 15 seeds per pot) filled with a potting mixture containing red soil, farmyard manure, and sand in 2:2:1 ( vol/vol/vol) ratio. Seeds of each genotype were sown in five pots. At the coleoptile stage, seedlings of both genotypes were spray-inoculated with a viable suspension of sporangia $\left(10^{6}\right.$ sporangia per $\mathrm{ml}$ of water) of $S$. graminicola (17). No downy mildew developed in IP 18292. At 20 days after sowing, seedlings were thinned to two per pot and allowed to self-pollinate. Tift 23DB developed $96 \%$ downy mildew. Plants were thinned to two diseased plants per pot. These plants were sprayed with Ridomil MZ 75 WP (1,000 $\mathrm{ppm}$ ) for recovery from downy mildew infection (18) and self-pollinated. This procedure of inoculation and recovery from the disease (Tift 23DB) and selfing (both IP 18292 and Tift 23DB) was continued for three generations. In the fourth generation in 1995, seven selfed progenies of IP 18292 and six of Tift 23DB were derived. These 13 progenies and downy mildew susceptible (HB 3 and 7042[S]) and resistant (ICML 16) (20) controls were inoculated with a homogenized population of $S$. graminicola (described below) using the seedling inoculation technique reported previously (21). Progenies of Tift 23DB developed $100 \%$ downy mildew, while those of IP 18292 remained disease-free. The resistant control (ICML 16) developed $15 \%$ downy mildew, while two susceptible controls, HB-3 and 7042(S), had 99 and $95 \%$ mean downy mildew incidence, respectively. A selected single plant derivative of IP 18292 was designated as downy mildew resistant Pennisetum (DMRP) 292 and that of Tift 23DB as downy mildew susceptible Pennisetum (DMSP) 23.

Crossing procedure. Using single-plant selections along with recessive morphological traits of each parent, $\mathrm{F}_{1}, \mathrm{~F}_{2}$, and backcross $(\mathrm{BC})$ generations were produced in the greenhouse. The two parents and the four hybrid generations $\left(\mathrm{F}_{1}, \mathrm{~F}_{2}, \mathrm{BC} 1\right.$, and $\mathrm{BC} 2)$ were inoculated with the homogenized pathogen population in four sequential replicated tests. During the three tests in the summer of 1996, temperature in the greenhouse ranged between 20 and $32^{\circ} \mathrm{C}$, and during the fourth test, in winter, the temperature ranged from 18 to $25^{\circ} \mathrm{C}$. Data from all tests were pooled for analysis, since the differences in downy mildew incidence levels among replications were not significant.

Homogenization of $S$. graminicola population. The highly downy mildew susceptible line 7042(S) was sown in a 10$\mathrm{cm}$-diameter pot filled with the previously described potting mixture. At the coleoptile stage, seedlings were inoculated with the sporangial suspension previously described. The sporangial inoculum was collected from an infected leaf of a fieldgrown 7042(S) plant. Inoculated plants were kept in a greenhouse at $25 \pm 2^{\circ} \mathrm{C}$ for disease development. Sporangial inoculum from a single leaf of a 30-day-old 7042(S) plant from the above pot was used to inoculate another set of five potted plants of 7042(S). Bulk sporangia from these five plants were multiplied on 7042(S). We refer to this product of serial passage as "homogenized" pathogen population. 


\section{RESULTS AND DISCUSSION}

All $F_{1}$ plants from the DMSP 23 by DMRP 292 cross were resistant (Table 1). In the $\mathrm{F}_{2}$ generation, the resistant and susceptible plants segregated in the ratio $3: 1$, and in the backcross to the susceptible parent, the resistant and susceptible plants segregated in a 1:1 ratio. There was no susceptible plant in the backcross to the resistant parent. Unexpectedly, two DMSP 23 plants in the control remained downy mildew free. These were probably escapes.

Although dominance of downy mildew resistance has been reported in the past, with one exception, the resistance was reported to be controlled by two to several genes (6-8). A complex mode of inheritance with incomplete dominance has also been reported $(2,4,9)$. IP 18292 may have more than one gene conferring resistance to downy mildew (8). However, we could detect only one gene that has been fixed in DMRP 292. Quantitative trait loci (QTL) analysis revealed that IP 18292 probably has two major genes for resistance, but only one gene with substantial effect on genetic variation could be detected on linkage group 2 (7; C. T. Hash, personal communication). Our results show that one gene with complete dominance was responsible for downy mildew resistance in DMRP 292. This gene therefore has a simple mode of inheritance, and its utilization for resistance is simple and straightforward. We designate this gene as $\mathrm{Rsg}_{1}$.

The necessity to homogenize the pathogen population and to derive single-plant selections from apparent inbred lines for genetic studies merits discussion. $S$. graminicola is a diploid pathogen, and the presence of heterothallism (11) in its sexual system provides ample opportunity for generation of new variability. The outbreeding nature of its host further adds to this complexity. Although most of the variability may not be agriculturally important, it can complicate results from precise genetic studies and lead to erroneous conclusions. The use of a single-spore culture is recommended for such studies, but the results obtained using such a culture with a very narrow genetic base may not be useful in conventional resistance breeding programs. Thus, we used a bulk of a random population. The population was passed

Table 1. Downy mildew reaction and segregation ratios in $\mathrm{F}_{2}$ and $\mathrm{BC}$ generations from the pearl millet cross DMSP $23 \times$ DMRP 292 in the greenhouse during 1996-97 at ICRISAT Asia Center, Patancheru

\begin{tabular}{lcccc}
\hline & \multicolumn{2}{c}{ Number of plants } & & \\
\cline { 2 - 3 } Generation & Resistant & Susceptible & Ratio $\mathbf{x}^{\mathbf{2}}$ & $\boldsymbol{P}$ value \\
\hline DMSP 23 $\times$ DMRP 292 F & 77 & 0 & $\ldots$ & $\ldots$ \\
DMSP 23 $\times$ DMRP 292 F & 202 & 63 & $3: 1$ & $0.95-0.50$ \\
DMSP 23 $\times($ DMSP 23 $\times$ DMRP 292) BC1 & 211 & 195 & $1: 1$ & $0.50-0.20$ \\
DMRP 292 (DMSP 23 $\times$ DMRP 292) BC2 & 230 & 0 & $\ldots$ & $\ldots$ \\
DMSP 23 & 2 & 240 & $\ldots$ & $\ldots$ \\
DMRP 292 & 185 & 0 & $\ldots$ & $\ldots$ \\
\hline
\end{tabular}

${ }^{\mathrm{a}}$ Pooled data from all tests. serially through a susceptible inbred line for three generations to obtain a population of individuals with similar pathogenic ability but not identical clones. Genetically, this population lies between populations from single spores and those from the field. We refer to this procedure as "homogenization." Although the source inoculum was collected and subsequently multiplied on a universally susceptible line 7042(S), this population did not necessarily represent the entire genetic variability present in our diseased plot; further studies are in progress. However, we believe that results from studies using such pathogen populations are applicable to breeding programs.

The presence of residual variability for resistance to downy mildew in apparently susceptible genotypes has been established (22). Similar variability for susceptibility in apparently resistant genotypes may also exist. The process of selfing and singleplant propagation was done to reveal such hidden variability, if any, and to facilitate the selection of single plant derivatives with complete resistance-susceptibility. In order that the gene(s) conferring residual variability for resistance to downy mildew from the susceptible parent does not interfere with the segregation pattern of resistance genes from the resistant parent, and vice versa, creation of homozygosity in both parents was considered absolutely necessary.

Therefore, the methodology used for selection of parents and pathogen population is believed to have been essential to arrive at the right conclusion. In all the previous studies on inheritance, not only were complete resistance or reliable screening techniques not available, but no attempt was made to make the parents homozygous and the pathogen population uniform.

Pearl millet is a protogynous species with a large number of small florets on its inflorescences. Therefore, chances of selfpollination of some florets, in the absence of emasculation for crossing, do exist. Use of recessive morphological markers such as the $d_{2}$-dwarf trait in the female (5) and white leaf sheath in the male (1) were important factors in ensuring $100 \%$ crossing in this study.
Of the three types of resistance-incomplete resistance $(12,22)$, complete resistance (15), and recovery resistance (19)that are available in pearl millet, the first type is the most commonly available and has been used commercially. Incomplete resistance may be oligogenic or polygenic, but the genes controlling it confer incomplete resistance and exhibit variable levels of dominance. The gene(s) controlling recovery resistance may have still a different kind of inheritance and dominance effect. Although future studies on inheritance of resistance are essential, it is equally important to judiciously use and deploy the array of resistance genes currently available for downy mildew resistance so that they can remain effective for a longer period of time.

\section{LITERATURE CITED}

1. Appa Rao, S., Mengesha, M. H., Rajagopal Reddy, C., and Saideswara Rao, Y. 1990. Genetics of white sheath and bleached leaf mutants in pearl millet. J. Hered. 81:159162.

2. Basavaraju, R., Safeeulla, K. M., and Murthy, B. R. 1980. The role of gene effects and heterosis for resistance to downy mildew in pearl millet. Ind. J. Genet. Plant Breed. 40:537-548.

3. Bouriquet, G. 1963. Lex principaux ennemis et maladies du sorgho et du mil en Afrique tropicale. (In French, summaries in English, Es.) Agron. Trop. 18(1):132-136.

4. Burton, G. W. 1967. Pearl millet Tift 23DA and Tift 23DB released GA. Agric. Res. 9:6.

5. Burton, G. W., Monson, W. G., Johnson, J. C. Jr., Lowrey, R. S., Chapmanand, H. D., and Marchant, W. H. 1969. Effect of the d2 gene on forage yield and quality of pearl millet. Agron. J. 61:607-612.

6. Deswal, D. P., and Govila, O. P. 1994. Genetics of resistance to downy mildew (Sclerospora graminicola) in pearl millet (Pennisetum glaucum). Indian J. Agric. Sci. 64:661-663.

7. Gill, K. S., Phul, S. S., Chahal, S. S., and Singh, N. B. 1978. Inheritance of resistance to downy mildew in pearl millet. Cereal Res. Comm. 1:71-74.

8. Jones, E. 1994. Mapping quantitative trait loci for resistance to downy mildew in pearl millet. Ph.D. thesis. School of Biological Sciences, University of Wales, Bangore Gnedd, UK. pp. 147-151.

9. Kataria, R. P., Yadav, H. P., Beniwal, C. R., and Narwal, M. S. 1994. Genetics of incidence of downy mildew in pearl millet (Pennisetum glaucum). Indian J. Agric. Sci. 64:664-666.

10. Mathur, R. L., and Daleda, G. C. 1971. Estimation of losses from 'green gar' disease (Sclerospora graminicola) of bajra and grain smut (Sphacelotheca sorghi) of Jowar in Rajasthan. Indian Phytopathol. 24:104

11. Michelmore, R. W., Pawar, M. N., and Williams, R. J. 1982. Heterothallism in Sclerospora graminicola. Phytopathology 72:13681372.

12. Rai, K. N., Talukdar, B. S., Singh, S. D., Rao, A. S., Rao, A. M., and Andrews, D. J. 1994 Registration of ICMP 423 parental line of pearl millet. Crop Sci. 34:1430.

13. Saccas, A. M. 1954. Les Champignons parasites des sorghos (Sorghum vulgare) et des pennicillariae (Pennisetum typhoideum) en Afrique Equatoriale Francaise. (In French, summaries in English, Es). Agron. Trop. 9:135-173, 263-301, 647-686. 
14. Safeeulla, K. M. 1977. Genetic vulnerability: The basis of recent epidemics in India. Ann. N.Y. Acad. Sci. 287:72-85.

15. Singh, S. D. 1995. Downy mildew of pearl millet. Plant Dis. 79:545-550.

16. Singh, S. D., Ball, S. L., and Thakur, D. P. 1987. Problems and strategies in the control of downy mildew. (Summaries in English, French) Pages 161-172 in: Proc. Int. Pearl Millet Workshop, 7-11 April 1986. International Crops Research Institute for the SemiArid Tropics, Patancheru, India.

17. Singh, S. D., and Gopinath, R. 1985. A seed- ling inoculation technique for detecting downy mildew resistance in pearl millet. Plant Dis. 69:582-584.

18. Singh, S. D., Gopinath, R., Luther, K. D. M. Reddy, P. M., and Pawar, M. N. 1984. Systemic remissive property of metalaxyl against downy mildew in pearl millet. Plant Dis. 68:668-670.

19. Singh, S. D., and King, S. B. 1988. Recovery resistance to downy mildew in pearl millet. Plant Dis. 72:425-428.

20. Singh, S. D., King, S. B., and Malla Reddy, P. 1990. Registration of five pearl millet germ- plasm sources with stable resistance to downy mildew. Crop. Sci. 30:1164.

21. Singh, S. D., King, S. B., and Werder, J. 1993 Downy mildew disease of pearl millet. (In English, summaries in French, Es.) ICRISAT Inform. Bull. 37. International Crops Research Institute for the Semi-Arid Tropics, Patancheru, India.

22. Singh, S. D., Williams, R. J., and Malla Reddy, P. 1988. Isolation of downy mildew resistant lines from a highly susceptible cultivar of pearl millet. Indian Phytopathol. 41:450-456. 